\title{
EFFICACY OF COMMERCIAL BACTERIOPHAGE PRODUCTS AGAINST ESKAPE PATHOGENS
}

\section{Kuptsov NS $\bowtie$, Kornienko MA, Gorodnichev RB, Danilov DI, Malakhova MV, Parfenova TV, Makarenko Gl, Shitikov EA, llina EN}

Federal Research and Clinical Center of Physical-Chemical Medicine of Federal Medical Biological Agency, Moscow, Russia

The ever-rising prevalence of multidrug-resistant bacteria necessitates the search for a therapeutic alternative to antibiotics. Using therapeutic products based on virulent bacteriophages might provide such an alternative. The aim of our study was to evaluate the efficacy of commercial phage products and natural bacteriophage monoisolates recovered from environmental sources against clinical strains of Enterococcus faecium, Staphylococcus aureus, Klebsiella pneumoniae, and Pseudomonas aeruginosa. We compiled a collection of 147 strains that were subsequently genotypes using the MLST method. The efficacy of bacteriophages was evaluated in spot tests. The highest efficacy was demonstrated by "Staphylococcal bacteriophage" (86\%, effective against $S$. aureus), "Purified polyvalent pyobacteriophage" (87.8\%, effective against $K$. pneumoniae), and a group of phage products against $P$. aeruginosa, including "Pseudomonas aeruginosa bacteriophage" (87.5\%), "Complex pyobacteriophage" (79.5-90\%) and "Purified polyvalent pyobacteriophage" (90-92.5\%). The efficacy of "Intesti bacteriophage", which targets E. faecium, was $4.2 \%$. The efficacy of commercial phage products against S. aureus and K. pneumoniae was higher than the efficacy of individual phage monoisolates (60\% for the S. aureus phage vB_SauP-436-3w and 5.9\% for the K. pneumoniae phage vB_Kp_M_ Seu621). Thus, all tested commercial phage products were highly effective against $P$. aeruginosa, $K$. pneumoniae and $S$. aureus. There are no commercial phage products on the market against other ESKAPE pathogens, including Acinetobacter baumannii and Enterobacter cloacae. Besides, there are no effective phage products against $E$. faecium. This dictates the need for new effective bacteriophages against these species.

Keywords: bacteriophages, phage therapy, microbiology, ESKAPE pathogens, bacteria

Funding: all study expenses were covered by the funds allocated for the State Assignment on the Development of a personalized approach to the therapy of infections using virulent bacteriophages (Code: Bacteriophage).

Acknowledgements: the authors thank the Center for Precision Genome Editing and Genetic Technologies for Biomedicine, the Federal Research and Clinical Center of Physical-Chemical Medicine of the Federal Medical Biological Agency for their help with bacterial gene sequencing and for subsequent multilocus sequencing typing.

Author contribution: Kuptsov NS — study plan; data acquisition and analysis; manuscript preparation; Kornienko MA — study plan; data analysis; manuscript preparation; Gorodnichev RB, Parfenova TV — data acquisition and analysis; Danilov DI, Malakhova MV — data acquisition; Makarenko Gl — sample collection; Shitikov EA - data analysis; manuscript preparation; llina EN — manuscript preparation.

Compliance with ethical standards: the study was carried out in strict compliance with the sanitary norms and epidemiological safety standards specified in the guidelines on the work with microorganisms belonging to hazard groups III-IV and causative agents of parasitic diseases (Guidelines 1.3.2322-08); supplementary guidelines № 1 to the guidelines on the work with microorganisms belonging to hazard groups III-IIV and causative agents of parasitic diseases (Guidelines 1.3.2518-09), sanitary and epidemiologic requirements for the handling of medical waste (Sanitary norms and regulations 2.1.7.2790-10), and Federal clinical recommendations on the rational use of bacteriophages in clinical and epidemiological practice.

$\triangle$ Correspondence should be addressed: Nikita S. Kuptsov

Malaya Pirogovskaya, 1a, Moscow, 119435; kuptsovns@gmail.com

Received: 06.05.2020 Accepted: 20.05.2020 Published online: 25.05.2020

DOI: $10.24075 /$ brsmu.2020.029

\section{ЭФФЕКТИВНОСТЬ ПРЕПАРАТОВ БАКТЕРИОФАГОВ ПРОТИВ ПАТОГЕНОВ ГРУППЫ ЕSКАРЕ}

Н. С. Купцов $\square$, М. А. Корниенко, Р. Б. Городничев, Д. И. Данилов, М. В. Малахова, Т. В. Парфенова, Г. И. Макаренко, Е. А. Шитиков, Е. Н. Ильина Федеральное государственное бюджетное учреждение «Федеральный научно-клинический центр физико-химической медицины Федерального медико-биологического агентства", Москва, Россия

Ежегодный рост числа случаев выявления бактерий с множественной лекарственной устойчивостью делает актуальной задачу поиска альтернативы применяемым антибиотикам. Такой альтернативой могут быть препараты на основе вирулентных бактериофагов. Целью работы было оценить эффективность коммерческих фаговых препаратов и моноизолятов бактериофагов, выделенных из природных источников, против клинических штаммов Enterococcus faecium, Staphylococcus aureus, Klebsiella pneumoniae и Pseudomonas aeruginosa. Была собрана коллекция из 147 штаммов, типированных методом МЛСТ. Оценку эффективности бактериофагов проводили методом спот-тестирования. Наиболее эффективными оказались препараты против S. aureus («Бактериофаг стафилококковый», 86\%), K. pneumoniae («Пиобактериофаг поливалентный очищенный», 87,8\%) и P. aeruginosa («Бактериофраг псевдомонас аеругиноза», 87,5\%; «Пиобактериофаг комплексный», 79,5-90\%; «Пиобактериофаг поливалентный очищенный», 90-92,5\%). Для E. faecium эффективность препарата «Интести-бактериофаг» составила лишь 4,2\%. При этом эффективность терапевтических препаратов, активных против S. aureus и K. pneumoniae, была выше эфффективности отдельных моноизолятов бактериофагов (фраг S. aureus vB_SauP-436-3w - 60\%, фаг K. pneumoniae vB_Kp_M_Seu621 - 5,9\%). Таким образом, исследуемые препараты обладают высокой активностью против штаммов P. aeruginosa, K. pneumoniae и S. aureus. В свою очередь препаратов, действующих против остальных членов группы ESKAPE-патогенов (Acinetobacter baumannii и Enterobacter cloacae), а также эффективных против E. fаесіuт, не представлено на рынке, что подчеркивает необходимость поиска новых бактериофагов.

Ключевые слова: бактериофаги, бактериофаговая терапия, микробиология, ESKAPE-патогены, бактерии

Финансирование: исследование выполнено за счет средств, предоставленных для выполнения государственного задания «Разработка персонализированного подхода терапии инфекционных процессов с применением вирулентных бактериофагов» (ШИФР: Бактериофаг).

Благодарности: авторы благодарят Центр высокоточного редактирования и генетических технологий для биомедицины ФГБУ ФНКЦ ФХМ ФМБА России за секвенирование бактериальных генов для мультилокусного секвенирования-типирования штаммов.

Вклад авторов: Н. С Купцов - план исследований, набор и обработка данных, написание статьи; М. А. Корниенко — план исследований, обработка данных, написание статьи; Р. Б. Городничев, Т. В. Парфенова - набор и обработка данных; Д. И. Данилов, М. В. Малахова - набор данных; Г. И. Макаренко - сбор материала; Е. А. Шитиков - обработка данных, написание статьи; Е. Н. Ильина - написание статьи.

Соблюдение этических стандартов: вся экспериментальная работа выполнена с соблюдением норм Санитарно-эпидемиологических правил «Безопасность работы с микроорганизмами III-IV групп патогенности (опасности) и возбудителями паразитарных болезней» СП 1.3.2322-08; Санитарноэпидемиологических правил СП 1.3.2518-09 - «Дополнения и изменения № 1 к санитарно-эпидемиологическим правилам «Безопасность работы с микроорганизмами III-IV групп патогенности (опасности) и возбудителями паразитарных болезней» СП 1.3.2322-08; Санитарно-эпидемиологических правил «Санитарно-эпидемиологические требования к обращению с медицинскими отходами» СанПиН 2.1.7.2790-10, а также Федеральных клинических рекомендаций «Рациональное применение бактериофагов в лечебной и противоэпидемической практике».

$\varangle$ Для корреспонденции: Никита Сергеевич Купцов

ул. Малая Пироговская, д. 1а, г. Москва, 119435; kuptsovns@gmail.com

Статья получена: 06.05.2020 Статья принята к печати: 20.05.2020 Опубликована онлайн: 25.05.2020

DOI: $10.24075 /$ vrgmu.2020.029 
Every year, multidrug resistant (MDR) bacteria are becoming more prevalent. MDR strains are defined as having resistance to three or more antibacterial drugs [1]. Bacterial infections caused by MDR strains pose a critical threat to global healthcare. Most MDR strains are found among the so called ESKAPE pathogens (an acronym for Enterococcus faecium, Staphylococcus aureus, Klebsiella pneumoniae, Acinetobacter baumannii, Pseudomonas aeruginosa, and Enterobacter spp.). These bacteria cause life-threatening nosocomial infections and are especially dangerous for individuals with compromised immunity and chronic conditions [2-4].

According to the World Health Organization, pathogenic bacteria can be classified in terms of threat prioritization as having critical, high or medium priority [1]. Carbapenemresistant $A$. baumannii, $P$. aeruginosa, Enterobacteriaceae spp., as well as $K$. pneumoniae, are critical priority pathogens. In some countries, the proportion of carbapenem-resistant isolates among $P$. aeruginosa and $K$. pneumoniae can be as high as 50 and 64\%, respectively [5]. Methicillin-resistant $S$. aureus (MRSA) and vancomycin-resistant $E$. faecium belong to the high-priority group. In some countries, MRSA strains amount to $43 \%$ of all $S$. aureus isolates, whereas vancomycinresistant E. faecium makes up 59.1\% [5]. The number of antibiotic-resistant isolates is constantly increasing.

Infections caused by drug-resistant ESKAPE pathogens dictate the need for novel therapeutic approaches. One of them involves using virulent bacteriophages as a complement or an alternative to antibacterial therapy. The first attempts to exploit bacteriophages in clinical practice were made in the early $20^{\text {th }}$ century. So far, phages have proved to be effective antibacterial agents [6, 7]. Using virulent bacteriophages as therapeutic agents has several advantages. Most importantly, their interaction with a bacterial cell does not depend on the resistance profile of the latter. Phages co-evolve with their bacterial hosts and thereby learn to overcome the host's defenses.

Phage products available on Russia's pharmaceutical market are cocktails composed of several virulent phages. Such cocktails allow targeting an array of different bacterial strains. In Russia, most commercial phage products are manufactured by two companies: Microgen Scientific and Production Association and Micromir Research and Production Center. The manufacturers claim that their phage cocktails are effective against ESKAPE pathogens, including E. faecium, $S$. aureus, K. pneumoniae, and $P$. aeruginosa. At present, there are no commercial phage preparations on the Russian market exerting activity against $A$. baumannii and Enterobacter spp. This emphasizes the importance of their development.

The aim of this work was to evaluate the efficacy of commercial phage cocktails and monoisolates of bacteriophages from environmental sources against clinical strains of $E$. faecium, $S$. aureus, $K$. pneumoniae, and $P$. aeruginosa.

\section{METHODS}

\section{Bacterial isolates}

Isolates of E. faecium, S. aureus, K. pneumoniae, and $P$. aeruginosa $(n=147)$ were obtained from the inpatients of the Federal Research and Clinical Center of Physical-Chemical Medicine of the Federal Medical Biological Agency in 20182019. The cultures were grown on Columbia agar or soya broth (both by Oxoid; UK) at $37^{\circ} \mathrm{C}$ for $18-24 \mathrm{~h}$.

Bacterial species were identified by means of direct mass spectrometry profiling of bacterial lysates as described in
[8]. A saturated solution of $\alpha$-cyano-4-hydroxycinnamicacid (Bruker Daltonics; Germany) in 50\% acetonitrile and 2.5\% trifluoroacetic acid was used as a matrix solution. Mass spectra were recorded on a Microflex MALDI TOF mass spectrometer (Bruker Daltonics; Germany). A bacterial test standard (Bruker Daltonics; Germany) was used for calibration. Mass spectra were recorded, processed and analyzed in flexControl 3.0 and flexAnalysis 3.0 (Bruker Daltonics; Germany). Species identification was aided by MALDI Biotyper 3.0 (Bruker Daltonics; Germany).

\section{Determining bacterial sensitivity to antibiotics}

Sensitivity of bacterial strains to antibiotics was evaluated by disk diffusion as recommended by the international Performance Standards for Antimicrobial Susceptibility Testing (Clinical and Laboratory Standards Institute) (CLSI) published in 2019 [9]. Gram-negative $K$. pneumoniae and P. aeruginosa were tested for sensitivity to ceftriaxone, gentamicin, ciprofloxacin, and meropenem. Gram-positive S. aureus and E. faecium were tested for sensitivity to erythromycin, ciprofloxacin and tetracycline. Additionally, S. aureus isolates were tested for resistance to oxacillin and gentamicin. Sensitivity of $E$. faecium to vancomycin was evaluated using a method of serial dilutions following CLSI recommendations [9].

\section{Molecular genetic testing of bacterial strains}

K. pneumoniae, $P$. aeruginosa and E. faecium strains were genotyped using multilocus sequence typing (MLST) following standard schemes [10-14]. For S. aureus, spa-typing was applied according to the standard protocol; this technique allows determining the sequence of the Staphylococcus protein A gene [15].

Bacterial DNA was isolated using a DNA-express kit (Lytech; Russia) following the manufacturer's protocol. DNA samples were stored at $-20{ }^{\circ} \mathrm{C}$. Genes targeted by genetic typing were amplified in a TETRAD DNA ENGINE thermocycler (MJ Research; USA). Amplification was carried out in $25 \mu \mathrm{l}$ of the reaction mix containing $66 \mathrm{mM}$ Tris- $\mathrm{HCl}(\mathrm{pH}$ 9), $16.6 \mathrm{mM}$ $\left(\mathrm{NH}_{4}\right)_{2} \mathrm{SO}_{4}, 2.5 \mathrm{mM} \mathrm{MgCl}_{2}, 250 \mu \mathrm{M}$ of each dNTP, 1 Taq DNA polymerase unit (Lytech; Russia), and $10 \mathrm{pmol}$ of primers. Amplification products were separated in $2 \%$ agarose gel stained with ethidium bromide for DNA visualization.

Sanger sequencing was performed in a 3730 DNA Analyzer (Thermo Fisher Scientific; UK). Gene sequences were analyzed in the Ridom StaphType TM software (Ridom GmbH; Würzburg, Germany) and Vector NTI Suite 9 (Thermo Fisher Scientific; UK). Allelic profiles and MLST types were determined by comparing the obtained nucleotide sequences to the sequences stored in the international PubMLST database [11].

\section{Commercial phage products}

In this study, we evaluated the efficacy of 14 commercial products of virulent bacteriophages manufactured by Microgen (Table 1). All phage products were bought at Moscow pharmacies and are approved for clinical use.

\section{Isolation of bacteriophages from environmental sources}

Bacteriophages capable of infecting some $K$. pneumoniae and $S$. aureus strains were isolated from water samples collected in different water reservoirs; isolation was performed using the enrichment culture method. Briefly, a $50 \mathrm{ml}$ water sample was 
Table 1. Commercial bacteriophage products used in the study

\begin{tabular}{|c|c|c|c|}
\hline Name & Activity spectrum & $\begin{array}{l}\text { Batch } \\
\text { number }\end{array}$ & Manufactured in \\
\hline \multirow{2}{*}{ "Staphylococcal bacteriophage" } & \multirow{2}{*}{ Staphylococcus aureus and some other coagulase-negative staphylococci } & N33 & Nizhny Novgorod \\
\hline & & P332 & Perm \\
\hline $\begin{array}{l}\text { "Pseudomonas aeruginosa } \\
\text { bacteriophage" }\end{array}$ & Pseudomonas aeruginosa & N7 & Nizhny Novgorod \\
\hline \multirow{2}{*}{$\begin{array}{l}\text { "Klebsiella pneumoniae purified } \\
\text { bacteriophage" }\end{array}$} & \multirow{2}{*}{ Klebsiella pneumoniae } & P252 & \multirow{2}{*}{ Perm } \\
\hline & & P251 & \\
\hline $\begin{array}{l}\text { "Klebsiella pneumoniae purified } \\
\text { polyvalent bacteriophage" }\end{array}$ & Klebsiella pneumoniae, Klebsiella ozaenae, Klebsiella rhinoscleromatis & U27 & Ufa \\
\hline \multirow[b]{2}{*}{ "Purified polyvalent pyobacteriophage" } & \multirow{2}{*}{$\begin{array}{l}\text { Staphylococcus spp, Streptococcus spp, Proteus spp, } \\
\text { Pseudomonas aeruginosa, Klebsiella pneumoniae, Escherichia coli }\end{array}$} & U1 & \multirow[b]{2}{*}{ Ufa } \\
\hline & & U25 & \\
\hline \multirow[b]{2}{*}{ "Complex pyobacteriophage" } & \multirow{2}{*}{$\begin{array}{l}\text { Staphylococcus spp, Enterococcus spp, Streptococcus spp, } \\
\text { enteropathogenic Escherichia coli, Proteus vulgaris, Proteus mirahilis, } \\
\text { Pseudomonas aeruginosa, Klebsiella pneumoniae, Klebsiella oxytoca }\end{array}$} & N74 & \multirow[b]{2}{*}{ Nizhny Novgorod } \\
\hline & & N45 & \\
\hline \multirow{4}{*}{ "Intesti bacteriophage" } & \multirow{4}{*}{$\begin{array}{l}\text { Shigella flexneri, Shigella sonnei, Salmonella typhimurium, Salmonella spp, } \\
\text { Escherichia coli, Proteus spp, Enterococcus spp, Staphylococcus spp, } \\
\text { Pseudomonas aeruginosa }\end{array}$} & N101 & \multirow{4}{*}{ Nizhny Novgorod } \\
\hline & & N123 & \\
\hline & & N86 & \\
\hline & & N175 & \\
\hline
\end{tabular}

filtered through a $0.45 \mu \mathrm{m}$ Millipore filter (Merck Millipore; USA). A 2x lysogeny broth (LB) (Oxoid; UK) was combined with the water sample; $300 \mu \mathrm{L}$ of the overnight bacterial culture were added to the mixture and incubated on a rocking shaker at $37^{\circ} \mathrm{C}$ for $18 \mathrm{~h}$. Then, bacterial cells were centrifuged at 3,500 $\mathrm{g}$, and the supernatant was filtered through a 0.22 $\mu \mathrm{m}$ Millipore filter (Merck Millipore; USA). Monoisolates were obtained through a series of 3 sequential isolations from negative colonies. The obtained bacteriophages were grown in $50 \mathrm{ml}$ of LB containing $300 \mu \mathrm{l}$ of the overnight bacterial culture. Bacteriophage concentrations in the phage lysate were measured using a classic double layer agar method proposed by A. Gratia [16].

A

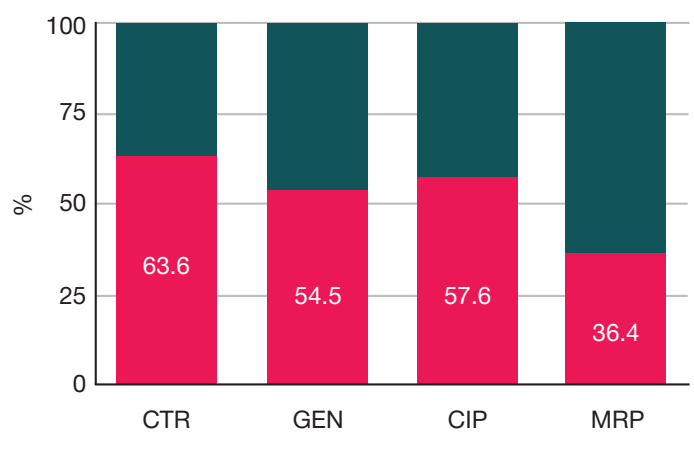

C

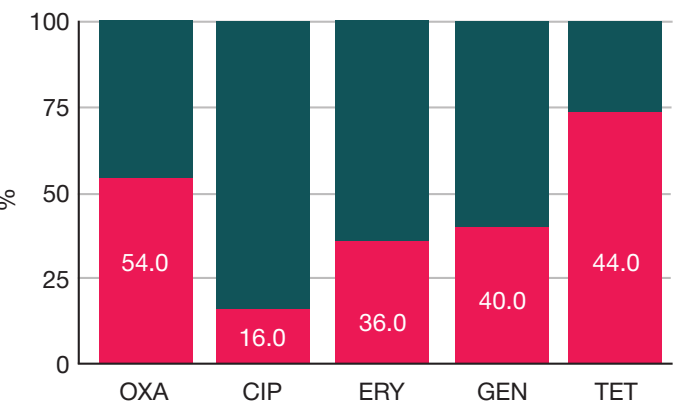

\section{Evaluating the efficacy of commercial phage products and monobacteriophage lysates}

The efficacy of lytic phages (titers of over $10^{7}$ ) was evaluated in a spot test. Briefly, $0.1 \mathrm{ml}$ of the overnight culture was combined with $0.6 \%$ semi-liquid LB agar. The resulting suspension was applied onto Petri dishes coated with 1.5\% LB agar. After the top LB agar layer hardened, $5 \mu$ of the studied phage was applied onto it and incubated at $37^{\circ} \mathrm{C}$ for $18-24 \mathrm{~h}$. In $24 \mathrm{~h}$, either individual negative colonies or a transparent lysis zone were observed where the agar drop had been applied. If this was the case, the bacterial strain was considered sensitive to the tested phage. In the absence of a lysis zone, the

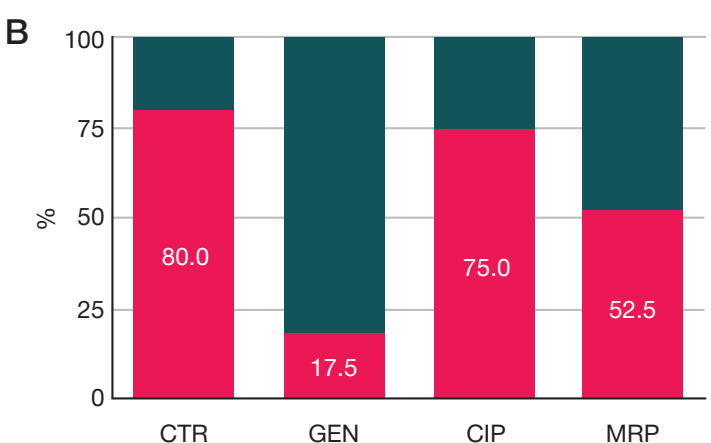

D

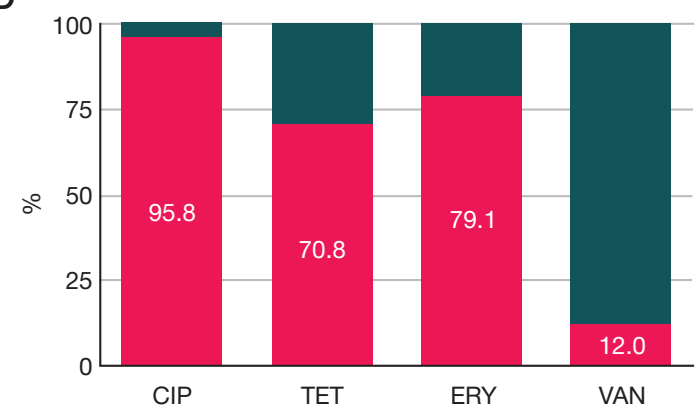

Fig. 1. Resistance to antibiotics among the strains of $K$. pneumoniae (A), P. aeruginosa (B), S. aureus (C), and $E$. faecium (D). The pink shows the proportion of resistant strains. CIP — ciprofloxacin, TET — tetracycline, ERY - erythromycin, MRP - meropenem, VAN — vancomycin, OXA — oxacillin, CTR — ceftriaxone, GEN - gentamicin 
bacterial strain was considered resistant to the tested phage. The efficacy of a phage against a certain bacterial strain was determined as percentage of susceptible bacterial strains of a given species in the total pool of strains of this species included in our collection.

\section{RESULTS}

We compiled a collection of 147 bacterial strains, which included 33 strains of $K$. pneumoniae (22.5\%), 40 strains of $P$. aeruginosa (27.2\%), 50 strains of S. aureus (34\%), and 24 strains of E. faecium (16.3\%). Susceptibility profiles were obtained for all strains included in the collection (Fig. 1).

Of $33 \mathrm{~K}$. pneumoniae strains, 9 (27.3\%) were sensitive to all antibiotics they were tested against, 4 (12.1\%) strains were resistant to only one antibacterial drug, and 17 (51.5\%) strains exhibited multidrug resistance. Of $40 \mathrm{P}$. aeruginosa strains included in the collection, $7(17.5 \%)$ were sensitive to all antibiotics they were tested against, 15 (37.5\%) were resistant to one antibacterial drug, and $6(15 \%)$ strains fell into the MDR category.

Of $50 \mathrm{~S}$. aureus strains included in the collection, 19 (38\%) were sensitive to all antibiotics they were tested against, 7 (14\%) were resistant to one antibacterial drug, and 22 (44\%) were classified as MDR. Twenty-seven (54\%) S. aureus strains were resistant to oxacillin. There were no susceptible strains among E. faecium isolates; 3 (12.5\%) of 24 E. faecium strains were resistant to one antibacterial drug, and 19 (19.2\%) were multidrug-resistant. Vancomycin-resistant $E$. faecium strains amounted to $12 \%$.

\section{A}
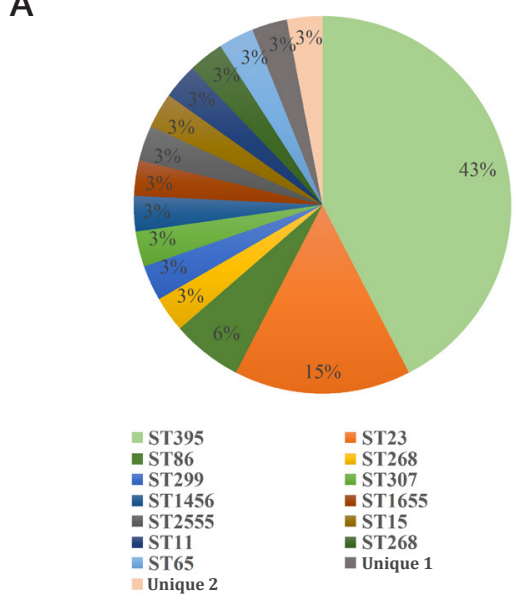

C

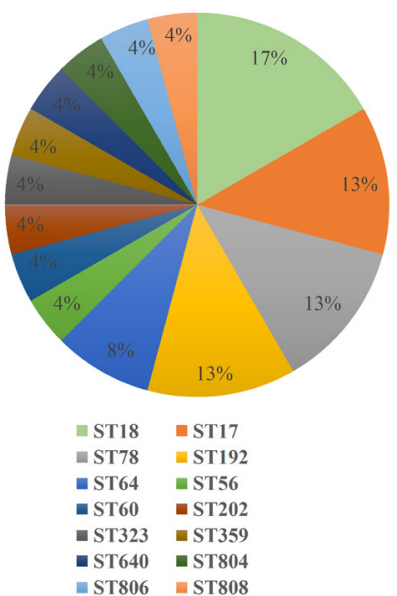

Using MLST, we identified 15 sequence types among K. pneumoniae strains (Fig. 2A). The most common of them were ST395 and ST23 represented by 14 (42.4\%) and 5 (15.2\%) strains, respectively. In addition, two unique sequence types were identified in this group of pathogens (2-1-1-1-9-4-1 and 2-1-1-1-9-4-18). According to MLST, $P$. aeruginosa strains fell into 26 different sequence types (Fig. 2B). ST12 was the most common sequence type among $P$. aeruginosa strains (5 out of total 40 strains; $12.5 \%$ ). In addition, 3 unique sequence types were identified: type 15-5-11-8-4-4-1 represented by 2 strains, type 15-2-11-3-3-38-3 represented by 2 strains and type 17-5-12-3-14-4-7 represented by 1 strain. E. faecium strains belonged to 12 different sequence types, the most common being ST18 (4 out of 24 strains; 16.7\%), ST17 (3 of 24 strains; $12.5 \%$ ), ST78 (3 of 24 strains; 12.5\%) and ST192 (3 of 24 strains; 12.5\%) (Fig. 2C).

Spa-typing revealed the diversity of $S$. aureus strains (Fig. 2D) in our collection. This species was represented by 18 spa-types; the types t008 and t308 prevailed, accounting for 20 (40\%) and $6(12 \%)$ of the total $50 \mathrm{~S}$. aureus strains.

The efficacy of 14 commercial phage products (see Table 1; Fig. 3) was tested on the compiled collection of characterized ESKAPE pathogens. The best effect against K. pneumoniae was observed for "Purified polyvalent pyobacteriophage", batch number U1, which killed 29 $(87.9 \%)$ of 33 K. pneumoniae strains (Fig. 3A). The efficacy of the commercial phage products against $P$. aeruginosa varied from 76.9 to $92.5 \%$ (Fig. 3B). "Staphylococcal bacteriophage" was effective against 43 (86\%) of 50 S. aureus strains (Fig. 3C). "Intesti bacteriophage", batch number P86, was the only

B

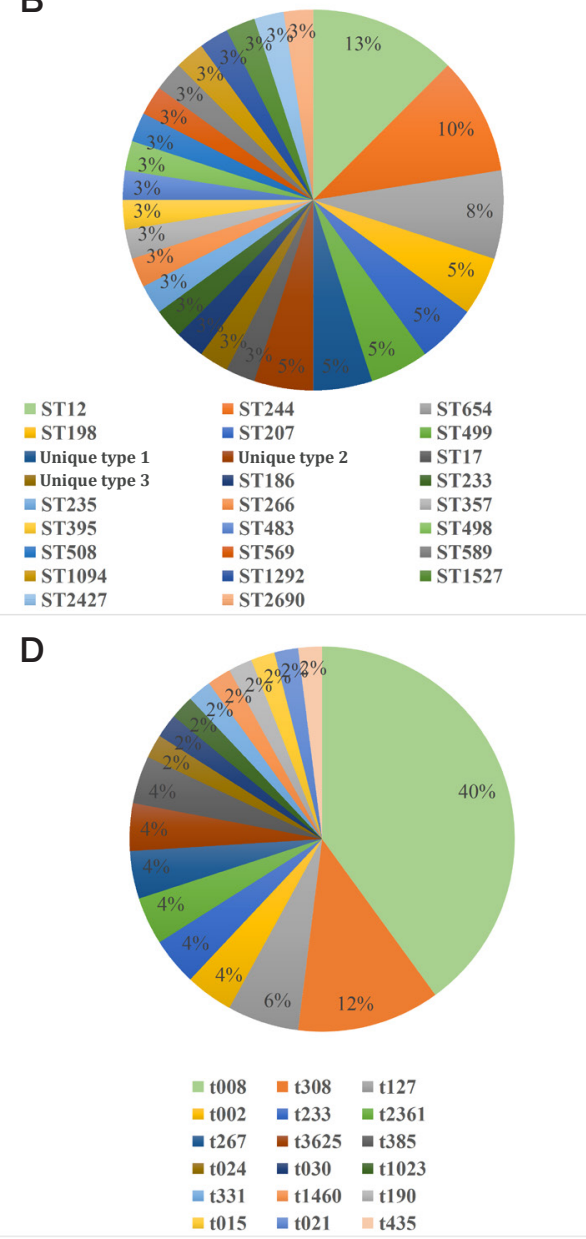

Fig. 2. Results of molecular genetic typing for K. pneumoniae (A) P. aeruginosa (B) E. faecium (C), and S. aureus (D) 
A

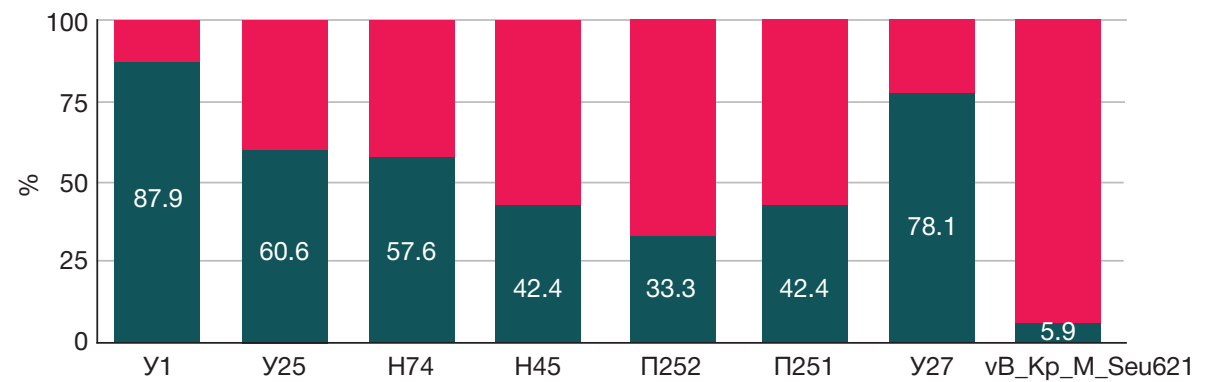

B

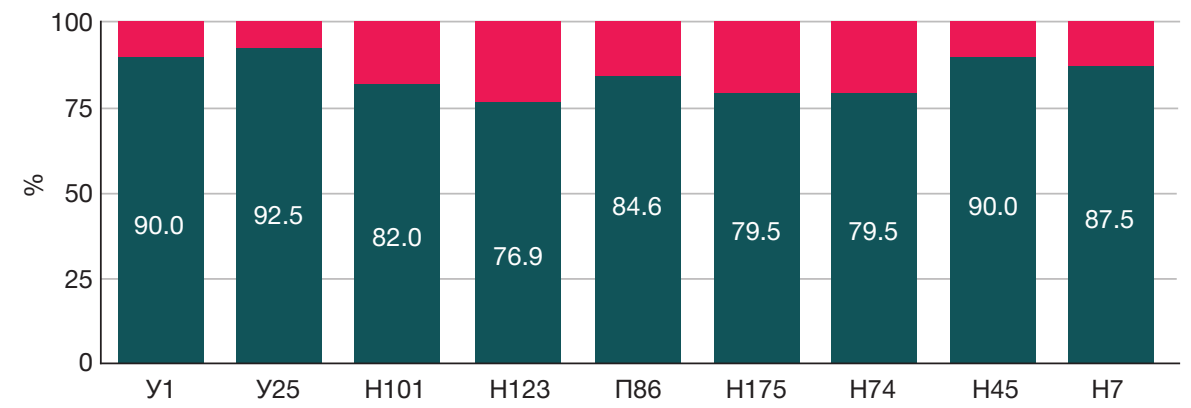

C

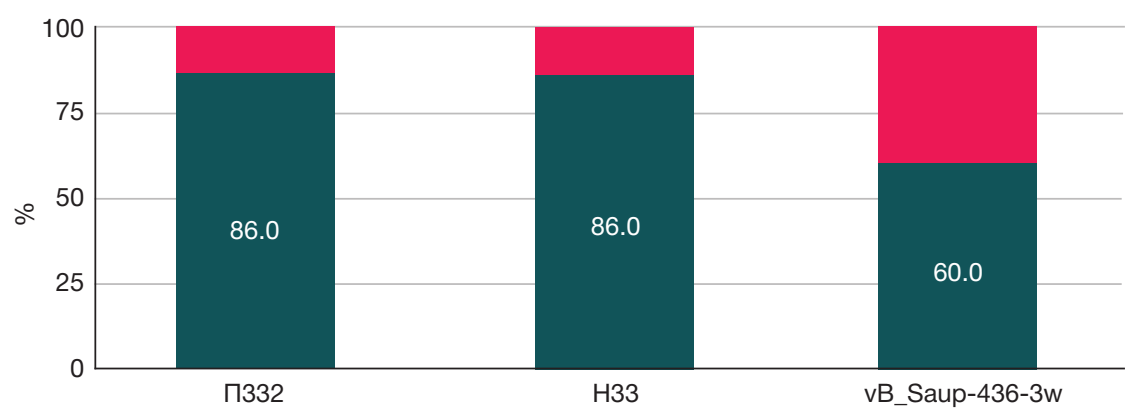

Fig. 3. The efficacy of commercial phage products against $K$. pneumoniae (A), P. aeruginosa (B) and S. aureus (C). The green shows the proportion of strains sensitive to the tested phage products. Batch numbers represent the tested products: "Purified polyvalent pyobacteriophage" (U1, U25); "Complex pyobacteriophage" (N74, N45); "Klebsiella pneumoniae purified bacteriophage" (P252, P251); "Klebsiella pneumoniae purified polyvalent bacteriophage" (U27); "Pseudomonas aeruginosa bacteriophage" (N7); "Staphylococcal bacteriophage" (P332, N33).

available bacteriophage against E. faecium; it successfully infected 24 (4.2\%) E. faecium strains.

To compare the efficacy of commercial phage products with that of natural phages, bacteriophage monoisolates exhibiting activity against $K$. pneumoniae and $S$. aureus were recovered from natural reservoirs (vB_Kp_M_Seu621 and vB_SauP-436$3 \mathrm{w}$, respectively). Their titers were $10^{12} \mathrm{PFU} / \mathrm{ml}$ (for vB_Kp_M_ Seu621) and 10 ${ }^{11} \mathrm{PFU} / \mathrm{ml}$ (for vB_SauP-436-3w), respectively. The efficacy of the vB_Kp_M_Seu621 and vB_SauP-436-3w monoisolates was 5. 9 and 60\%, respectively (see Fig. 3A and 3C).

\section{DISCUSSION}

The efficacy of polyvalent phage products against K. pneumoniae varied from 42.4 to $87.9 \%$; for monoisolates, this range was narrower: from 33.3 to $78.1 \%$ (see Fig. $3 \mathrm{~A}$ ). This suggests that the phage cocktails used in the study differed in their composition and should be updated and tested against currently circulating bacterial strains. The efficacy of the phage vB_Kp_M_Seu621 (5.9\%) isolated from environmental sources was much lower than the efficacy of the tested commercial phage products which might be associated with the diversity of $K$. pneumoniae capsule types. The capsule can serve as a receptor for bacteriophages and determine the efficacy of interaction between the phage and its host [17].
It should be noted that almost all strains of $K$. pneumoniae included in the collection (32 of 33; 97.9\%) were sensitive to at least one of the tested phage products. There was no significant difference in the efficacy of lysis between MDR and susceptible strains. The majority of MDR strains belonged to the sequence type ST395. Strains of this sequence type are very common among nosocomial pathogens and are associated with the spread of the blaOXA-48 gene, which confers resistance to $\beta$-lactams [18]. MDR strains representing this sequence type were susceptible to "Purified polyvalent pyobacteriophage" (U1); the efficacy of this phage product against ST395 strains was $81.8 \%$ (9 of 11). It also caused lysis of other MDR strains of K. pneumoniae belonging to the types ST15, ST23, ST268.

The highest efficacy of virulent phages was observed for $P$. aeruginosa strains. The efficacy of polyvalent phage products against this pathogen was $76.2-90 \%$, whereas the efficacy of monovalent phage products was $87.5 \%$ (see Fig. 3B). These findings correlate with previously published data. A Turkish study carried out on a small sample of $10 P$. aeruginosa strains demonstrated that the efficacy of "Complex pyobacteriophage" and "Intesti bacteriophage" was 90 and $80 \%$, respectively [19].

Similar to their effect on K. pneumoniae, the tested products caused lysis of almost all $P$. aeruginosa strains included in our collection (39 of 40; $97.5 \%$ ). MDR strains represented by the types ST235, ST357 and ST654 were successfully lysed by the majority of the tested phage preparations. 
Monovalent bacteriophage products demonstrated 86\% efficacy against S. aureus ("Staphylococcal bacteriophage", Fig. 3C). High efficacy of the phage product was earlier reported by other researchers. For example, the efficacy of the phage vB_SauM-fRuSau02 isolated from this commercial product was previously evaluated against 135 staph strains, including 30 strains of coagulase-negative staphylococci [20]. Notably, S. aureus strains used in the study had different origins: 51 strains were isolated from humans, whereas 54 strains, from pigs. The efficacy of the phage vB_SauM-fRuSau02 was very high (96\%) against S. aureus isolated from humans. In turn, the efficacy of this phage against coagulase-negative staphylococci species and $S$. aureus strains isolated from animals was lower (50 and 33\%, respectively) [20]. Another study investigated the efficacy of the commercial phage product "Stafal phage" (Bohemia Pharmaceuticals; Czech Republic). The study revealed that bacteriophages isolated from this preparation effectively killed $83 \%$ of MRSA and $99 \%$ of MSSA (methicillin susceptible Staphylococcus aureus) [21].

In our study, all MRSA, as well as MDR strains, were sensitive to "Staphylococcal bacteriophage" (batch number N33). One more MRSA strain from the MDR group was sensitive to another batch of this commercial product (P332). This strain was represented by the spa-type t127.

The efficacy of the phage monoisolate vB_SauP-436$3 \mathrm{w}$ against the strains included in our collection was lower (30 of 50; $60 \%$ ) than the efficacy of the commercial product "Staphylococcal bacteriophage" (43 of 50; 86\%), but still significantly higher than the efficacy of the phage vB_Kp_M_ Seu621, which effectively killed $K$. pneumoniae. This can be explained by the fact that receptors for staphylophages are represented by teichoic acids of bacterial cells [22], whose variability is much lower than that of gram-negative bacteria capsules.

The efficacy of all tested commercial phage products against $E$. faecium was poor (1 of $24 ; 4.2 \%$ ). The only strain sensitive to the tested phages was represented by the type
ST-17. Bacteriophages that exert activity against this species are listed as ingredients of commercial phage products, which are claimed to have a broad activity spectrum. Monovalent lytic phage products against $E$. faecium are not available on the Russian market.

A possible correlation between a bacterial strain's resistance to a phage and its resistance to antibacterial agents might have serious clinical implications. Another important finding would be a correlation between the resistance of a bacterial strain to a phage and the clonal complex the bacterium belonged to. In this study, we conducted a search for such correlations. We established that phage products induced lysis of both susceptible and sensitive (in terms of antibiotic resistance) bacteria. This is a crucial factor in deciding whether phages can be used as a clinical alternative to antibiotics. We established no correlations between the sensitivity of bacterial strains to the tested phages and their sensitivity to antibacterial agents ( $p>0.05$ ). We also found that bacterial strains representing one sequence type could be sensitive or resistant to a phage. This was true for all tested bacterial species. Thus, there was no clear correlation between the type of interaction between a phage and a bacterial cell, and a bacterial MLST sequence type $(p>0.05)$.

\section{CONCLUSION}

We found that strains included in our collection belonged to different genetic groups and have increased resistance to antimicrobial drugs, which makes them suitable for investigating the efficacy of commercial phage products. Commercial phage products available on the Russian market are highly effective against such ESKAPE pathogens as $P$. aeruginosa and $S$. aureus. However, not all tested phage products were equally effective against $K$. pneumoniae. Phage cocktails should be preferred to monovalent phages in the therapy of infections caused by gram-negative microorganisms, including K. pneumoniae.

\section{References}

1. World Health Organization. Antimicrobial resistance: global report on surveillance 2014. World Heal Organ. 2014: 1-257.

2. Rice LB. Progress and Challenges in Implementing the Research on ESKAPE Pathogens. Infect Control Hosp Epidemiol. Cambridge University Press (CUP). 2010; 31 (S1): S7-S10.

3. Zemko VY, Okulich VK, Dzyadzko AM. Monitoring the antibiotic resistance in the intensive care unit of a multidisciplinary hospital. Transplantologiya. The Russian Journal of Transplantation. 2018; 10 (4): 284-97.

4. Skleenova EYu, Azizov IS, Shek EA, Edelstein MV, Kozlov RS, Dekhnich AV. Pseudomonas aeruginosa: the history of one of the most successful nosocomial pathogens in Russian hospitals. Clin Microbiol Antimicrob Chemother. 2018; 3: 164-71.

5. European Centre for Disease Prevention and Control. Surveillance of antimicrobial resistance in Europe 2018. Stockholm: ECDC, 2019

6. Jennes $\mathrm{S}$, et al. Use of bacteriophages in the treatment of colistinonly-sensitive Pseudomonas aeruginosa septicaemia in a patient with acute kidney injury-a case report. Critical Care. 2017; 21 (1).

7. Breederveld RS. Phage therapy 2.0: where do we stand? The Lancet Infectious Diseases. 2019; 19 (1): 2-3.

8. Kornienko MA, llina EN, Borovskaya AD, Edelstein MV, Sukhorukova MV, Kostrzewa M, et al. Strain differentiation of staphylococcus aureus by means of direct maldi tof mass spectrometry profiling. Biomeditsinskaya Khimiya. 2012; 58 (5): 501-13. Russian.

9. M100 Performance Standards for Antimicrobial Susceptibility Testing An informational supplement for global application developed through the Clinical and Laboratory Standards Institute consensus process. 29th Edition. January 2019.

10. Institut Pasteur MLST databases and software. Klebsiella pneumonia: Available from: https://bigsdb.pasteur.fr/klebsiella/ klebsiella.html.

11. Pubmlst: Public databases for molecular typing and microbial genome diversity. Available from: https://pubmlst.org/databases/.

12. Diancourt $L$, et al. Multilocus sequence typing of Klebsiella pneumoniae nosocomial isolates. J Clin Microbiol. 2005; 43 (8): 4178-82.

13. Jolley KA, Bray JE, Maiden MCJ. Open-access bacterial population genomics: BIGSdb software, the PubMLST.org website and their applications. Wellcome open Res. 2018; 3: 124

14. Pubmlst: Public databases for molecular typing and microbial genome diversity. Enterococcus faecium. Available from: https:// pubmlst.org/efaecium/.

15. Harmsen D, et al. Typing of Methicillin-Resistant Staphylococcus aureus in a University Hospital Setting by Using Novel Software for spa Repeat Determination and Database Management. J Clin Microbiol. 2003; 41 (12): 5442-8.

16. Mazzocco A, et al. Enumeration of bacteriophages using the small drop plaque assay system. Methods Mol Biol. 2009; 501: 81-85.

17. Lin $\mathrm{T}-\mathrm{L}$, et al. Isolation of a bacteriophage and its depolymerase 
specific for K1 capsule of Klebsiella pneumoniae: implication in typing and treatment. J Infect Dis. 2014; 210 (11): 1734-44.

18. Cubero $M$, et al. Hypervirulent Klebsiella pneumoniae clones causing bacteraemia in adults in a teaching hospital in Barcelona, Spain (2007-2013). Clin Microbiol Infect. 2016; 22 (2): 154-60.

19. Ozkan I, et al. Lytic Activity of Various Phage Cocktails on Multidrug-Resistant Bacteria. Clin Invest Med. 2016; 39 (6): 27504

20. Leskinen $\mathrm{K}$, et al. Characterization of vB_SauM-fRuSau02, a

\section{Литература}

1. World Health Organization. Antimicrobial resistance: global report on surveillance 2014. World Heal Organ. 2014: 1-257.

2. Rice LB. Progress and Challenges in Implementing the Research on ESKAPE Pathogens. Infect Control Hosp Epidemiol. Cambridge University Press (CUP). 2010; 31 (S1): S7-S10.

3. Земко В. Ю., Окулич В. К., Дзядзько А. М. Мониторинг антибиотикорезистентности микроорганизмов в отделении реанимации и интенсивной терапии многопрофильного стационара. Трансплантология. 2018; 10 (4): 284-97.

4. Склеенова Е. Ю. и др. Pseudomonas aeruginosa в РФ: история одного из наиболее успешных нозокомиальных патогенов. Клиническая микробиология и антимикробная химиотерапия. 2018; 3: 164-71.

5. European Centre for Disease Prevention and Control. Surveillance of antimicrobial resistance in Europe 2018. Stockholm: ECDC, 2019.

6. Jennes $\mathrm{S}$, et al. Use of bacteriophages in the treatment of colistinonly-sensitive Pseudomonas aeruginosa septicaemia in a patient with acute kidney injury-a case report. Critical Care. 2017; 21 (1).

7. Breederveld RS. Phage therapy 2.0: where do we stand? The Lancet Infectious Diseases. 2019; 19 (1): 2-3.

8. Корниенко М. А., Ильина Е. Н., Боровская А. Д., Эдельштейн М. В. Сухорукова М. В., Кострцева М. и др. Штаммовая классификация staphylococcus aureus посредством прямого масс-спектрометрического профилирования. Биомедицинская химия. 2012; 58 (5): 501-13.

9. M100 Performance Standards for Antimicrobial Susceptibility Testing An informational supplement for global application developed through the Clinical and Laboratory Standards Institute consensus process. 29th Edition. January 2019.

10. Institut Pasteur MLST databases and software. Klebsiella pneumonia: Доступно по ссылке: https://bigsdb.pasteur.fr/ klebsiella/klebsiella.html.

11. Pubmlst: Public databases for molecular typing and microbial genome diversity. Доступно по ссылке: https://pubmlst.org/ twort-like bacteriophage isolated from a therapeutic phage cocktail. Viruses. 2017; 9 (9): E258.

21. Dvořáčková $M$, et al. Antimicrobial effect of commercial phage preparation Stafal ${ }^{\circledast}$ on biofilm and planktonic forms of methicillinresistant Staphylococcus aureus. Folia Microbiol. 2019; 64 (1): $121-26$.

22. Xia $G$, et al. Wall teichoic acid-dependent adsorption of staphylococcal siphovirus and myovirus. J Bacteriol. 2011; 193 (5): 4006-9.

databases/.

12. Diancourt $L$, et al. Multilocus sequence typing of Klebsiella pneumoniae nosocomial isolates. J Clin Microbiol. 2005; 43 (8): 4178-82.

13. Jolley KA, Bray JE, Maiden MCJ. Open-access bacterial population genomics: BIGSdb software, the PubMLST.org website and their applications. Wellcome open Res. 2018; 3: 124.

14. Pubmlst: Public databases for molecular typing and microbial genome diversity. Enterococcus faecium. Доступно по ссылке: https://pubmlst.org/efaecium/.

15. Harmsen D, et al. Typing of Methicillin-Resistant Staphylococcus aureus in a University Hospital Setting by Using Novel Software for spa Repeat Determination and Database Management. J Clin Microbiol. 2003; 41 (12): 5442-8.

16. Mazzocco A, et al. Enumeration of bacteriophages using the small drop plaque assay system. Methods Mol Biol. 2009; 501: $81-85$.

17. Lin $\mathrm{T}-\mathrm{L}$, et al. Isolation of a bacteriophage and its depolymerase specific for $\mathrm{K} 1$ capsule of Klebsiella pneumoniae: implication in typing and treatment. J Infect Dis. 2014; 210 (11): 1734-44.

18. Cubero $\mathrm{M}$, et al. Hypervirulent Klebsiella pneumoniae clones causing bacteraemia in adults in a teaching hospital in Barcelona, Spain (2007-2013). Clin Microbiol Infect. 2016; 22 (2): 154-60.

19. Ozkan I, et al. Lytic Activity of Various Phage Cocktails on Multidrug-Resistant Bacteria. Clin Invest Med. 2016; 39 (6): 27504.

20. Leskinen $\mathrm{K}$, et al. Characterization of vB SauM-fRuSau02, a twort-like bacteriophage isolated from a therapeutic phage cocktail. Viruses. 2017; 9 (9): E258.

21. Dvořáčková $M$, et al. Antimicrobial effect of commercial phage preparation Stafal ${ }^{\circledR}$ on biofilm and planktonic forms of methicillinresistant Staphylococcus aureus. Folia Microbiol. 2019; 64 (1): $121-26$.

22. Xia $G$, et al. Wall teichoic acid-dependent adsorption of staphylococcal siphovirus and myovirus. J Bacteriol. 2011; 193 (5): 4006-9. 